\section{CIENCIA, POLÍTICA Y EL AGOTAMIENTO DEL MODELO HABITACIONAL CHILENO}

Walter A. Imilan

\section{SCIENCE, POLITICS AND THE OBSOLESCENCE OF THE CHILEAN HOUSING SYSTEM}

\author{
Walter A. Imilan
}

"Chile has changed" was constantly repeated by President-elect Ms. Bachelet during the presidential campaign at the end of 2013. On the one side, citizens would be developing a new awareness of their rights, facing the orientation of a State that over the last 30 years has regarded areas such as education, health and housing as goods regulated by the market, thus limiting its action to subsidiarity. On the other side, the Chilean housing systemhas started to show clear signs of obsolescence. The increase in the supply of these goods has been possible through the emergence of poorly regulated markets whose negative effects cannot be overlooked. In 2011, education triggered the debate along environmental protests which were 
educación inició el debate junto a movilizaciones ambientales seguidas por las críticas al sistema de pensiones y de salud. El modelo de vivienda social, si bien no se encuentra en la primera línea de la crítica a nivel país, una serie de eventos en años recientes parecen indicar su agotamiento: dificultades en la reconstrucción post terremoto y maremoto del 2010 en áreas no urbanas, empeoramiento de la localización y baja calidad e innovación de la vivienda social, entre las más evidentes.

Nunca antes en la historia se habían construido tantas viviendas sociales en Chile como en los últimos 20 años. A fines de 1990's se alcanzaron las cien mil unidades anuales. El imperativo era disminuir el déficit habitacional y fomentar la emergencia de un mercado de vivienda social que fomentara la movilidad social de los nuevos propietarios. De paso, la industria inmobiliaria se beneficiaba de gigantescos proyectos construidos en la periferia, concentrando población vulnerable merced de la rentabilidad extraída del suelo más barato. Hace una década ya se evidenció que ese modelo, lejos de ser un primer escalón en la movilidad social de las familias, generaba un nuevo tipo de exclusión. Los gigantescos asentamientos han devenido en áreas de pobreza, cuyo principal promotor ha sido el mismo Estado a través de sus políticas.

Recientemente se ha iniciado la demolición de cientos de viviendas ubicadas en la periferia de followed by criticisms of the pension and health systems. Though not widely criticized, a series of events reveal a possible obsolescence of the social housing system: difficulties to rebuild the country in non-urban areas after the 2010 earthquake and tsunami and the worsening of location, low quality and lack of innovation of the social housing.

Never before in the history of Chile so many social housing have been built as in the last 20 years. At the end of the 1990s, the number of dwellings built reached 100,000 units per year. The challenge was to reduce the housing deficit and encourage the emergence of a social housing market that promoted social mobility among new owners. At the same time, the real estate industry was benefitting from large-scale projects built in the periurban area, concentrating vulnerable populations and profiting from low-priced land. A decade ago it was clear that this system generated a new type of exclusion rather than providing social mobility to families. These large settlements became poverty areas in which the State, through public policies, acted as the main promoter of such a situation.

Recently, hundreds of housing units located in the peri-urban area of Santiago and built only 15 years ago have been demolished. Those affected were offered new dwellings, a "second chance", (the eponymous name of the Government Program). However, the new units are located further away from the city; today, the price of land only allows 
Santiago, unidades habitacionales construidas hace apenas 15 años. A la población afectada se le ofrece una nueva vivienda, una "segunda oportunidad", tal como se llama el Programa de Gobierno; sin embargo, la nueva vivienda se encuentra aún más alejada de la ciudad: en la actualidad los precios de suelo sólo permiten la localización de vivienda social en la extra-periferia de Santiago. La segunda solución no parece ser mejor que la primera. El problema subyace en pensar que el mismo modelo que ha evidenciado su fracaso podrá desarrollar mejores soluciones. La evidencia en este caso es suficientemente poderosa para pensar en el agotamiento del modelo.

Decenas de investigadores han indagado en los efectos menos visibles de la política chilena promocionada por sus grandes cifras de construcción. Muchos de los hallazgos han sido publicados por Revista INVI, generando debate entre los especialistas. Foros y conferencias suelen ser espacios de lamentación de la comunidad académica respecto a los ya evidentes efectos negativos, mientras que operadores políticos, representantes de gremios y lobistas han preferido invisibilizarlos en cada reforma o "perfeccionamiento" del modelo llevado a cabo.

El influyente sociólogo urbano de la Alemania pos reunificación Harmut Haussermann, solía bajar la ansiedad de los investigadores urbanos señalado que a partir de su experiencia que la política building social housing in the extra-periphery area of Santiago. Thus, the second solution does not seem to be better than the first one. The issue lies in thinking that the same system that has failed may be able to provide better solutions. In this case, evidence point to the obsolescence of this system.

Dozens of researchers have delved into the less visible effects of the Chilean policy that have been promoted by large construction numbers. A considerable amount of findings have been published by Revista INVI, fostering debate among experts. Forums and conferences tend to be spaces in which the academic community regrets the clear negative effects of this system, while at the same time political operators, union representatives and lobbyists prefer to hide these problems every time this system is reformed or "improved".

Influential post-unification German urban sociologist HarmutHaussermann used to reduce the concerns of urban experts by stating that, according to his experience, politics will always be 15 or 20 years behind research. It takes some time for scientific findings to be assumed by public policy and, although a large number of them will never be considered in their respective fields, critical thinking and the desire to enlighten the darkest dimensions of reality must not be discouraged. The latter is in line with the objective of Revista INVI, which is to promote the labor of scientists 
siempre se movería 15 o 20 años más tarde que la investigación. Los hallazgos científicos suelen tomar su tiempo para ser asumidos por la política pública, y si bien muchos de ellos nunca serán considerados en virtud de la competencia en la cual se baten, este hecho no debe desincentivar el pensamiento crítico y el afán de iluminar las dimensiones más ocultas de la realidad. El objetivo de Revista INVI es justamente este, promover la acción del científico en el ámbito de lo público, que, tal como lo identificó Max Weber, involucra un oficio distinto al del político.

Cuando se evidencia el agotamiento de los modelos es necesario contar con reflexión e investigación empírica que provea de argumentos críticos y de propuestas para abrir caminos a seguir. El conjunto de textos que se presentan en el actual número son un aporte, justamente, para forjar el debate, son "buenos para pensar" el estado actual y proyección de las políticas.

El artículo que abre el presente número de Revista INVI aborda la principal fuerza de construcción de ciudad en América Latina: el asentamiento informal. En el texto "Un análisis comparado sobre la implementación de políticas de regularización de asentamientos informales en Argentina, Brasil y México" de María Mercedes Di Virgilio, Tomás Alejandro Guevara y María Soledad Arqueros, se revista el estado actual de los procesos de formalización en tres países de la región. Resulta in the public domain; in the words of Max Weber, such an action involves an occupation different than politics.

When systems become evidentlyobsoletes, there is a need to provide reflections and empirical research in order to contribute critical arguments and proposals to open new paths. The collection of papers offered in this issue are a contribution to shape a new debate, they are "good to think" about the current state and projection of politics.

The first paper offered in this issue of Revista INVI addresses the main force of city construction in Latin America: the informal settlement. This piece, entitled "A Comparative Analysis of the Implementation of Regulatory Policies of Informal Settlements in Argentina, Brazil and Mexico", written by Maria Mercedes Di Virgilio, Tomas Alejandro Guevara and Maria Soledad Arqueros, examines the current state of formalization processes in three countries of the region. It is interesting to discover how a common denominator of urban development in Latin American has been addressed in different ways.

The second paper, "Accessibility and the Value of Land as the Criteria for a Rational Localization of Rural Social Housing in San Bernardo and Calera de Tango", co-authored by Alejandro Salazar Burrows and Tomas Cox Oettinger, proposes a discussion on the formulation of indicators for the location of social housing in rural areas. To this end, 
interesante explorar en cómo un denominador común del desarrollo urbano latinoamericano ha sido abordado de formas diversas.

El artículo "Accesibilidad y valor de suelo como criterios para una localización racional de vivienda social rural en las comunas de San Bernardo y Calera de Tango, Chile", de Alejandro Salazar Burrows y Tomás Cox Oettinger, plantea discutir la formulación de indicadores para la localización de vivienda social en sectores rurales. Con este fin, el texto presenta un debate de gran relevancia para replantear la localización de vivienda social en territorios camino a constituirse en regiones urbanas. En este sentido, los autores proponen trabajar en torno a la accesibilidad que permita la inserción en redes, de forma que la vivienda sea un aporte al mejoramiento en la calidad de vida global. El artículo expresa la creciente necesidad de traer al primer plano de las políticas urbano habitacionales la movilidad cotidiana y accesibilidad como dimensiones centrales del hábitat residencial.

El texto "Condiciones de forma y desempeño energético de viviendas unifamiliares en el centro-sur de Chile", de Rodrigo García Alvarado y Alex González, presenta los resultados de experimentación con diversas tipologías de vivienda en torno a sus desempeños energéticos. En años recientes la eficiencia energética de la vivienda ha devenido en preocupación creciente en Chile. Algunos cambios se han observado en el mercado privado de the paper offers an important debate to rethink of the location of housing in territories that are on track to become urban regions. In this sense, the authors of this research provide insights about how accessibility allows the insertion in networks, so that housing may become a contribution to the improvement of quality of life. The paper reveals the growing need to bring daily mobility and accessibility into the focus of urban-housing policies as central dimensions of residential habitat.

The contribution "Form and Energy Performance Conditions of Single-Family Housing in CentralSouth Chile", prepared by Rodrigo Garcia Alvarado and Alex Gonzalez, offers the results of experiments carried out in different housing typologies in relation to their energy performance. In recent years, housing energy efficiency has become a growing concern in Chile. In this way, there have been some changes in the private real estate market, which identifies energy efficiency as a highly demanded feature and a desired item. However, these changes are mainly the result of the implementation of a governmental program focused on social housing. The paper addresses an innovative field of work that requires a deep knowledge to develop housing policies and construction guidelines in line with the local climate and housing practices.

In May, 2008, the Chaiten volcano in southern Chile began to erupt, forcing the evacuation of 
viviendas, que ven la eficiencia energética como un atributo deseable por la demanda, pero, por sobre todo, por la implementación de un programa gubernamental orientado a la vivienda social. El texto aborda un campo de trabajo innovador que requiere de conocimiento fundado para desarrollar políticas de vivienda y normas de construcción acordes al clima y prácticas de habitar localmente situadas.

En mayo de 2008 el volcán Chaitén en el Sur de Chile entró en erupción obligando a la evacuación de los habitantes de la localidad del mismo nombre. El artículo "Sujetos en emergencia: acciones colectivas de resistencia y enfrentamiento del riesgo ante desastres; el caso de Chaitén, Chile", de Ana María Ugarte y Marcela Salgado, presenta la relación conflictiva entre la población afectada y las políticas públicas implementadas hasta la actualidad. Pese a la larga historia de desastres socionaturales en Chile es sólo a partir de la erupción del Chaitén y el terremoto y maremoto de febrero de 2010 que se ha sistematizado y teorizado respecto a políticas públicas, riesgo y procesos de reconstrucción. El texto funciona como una bitácora de las valoraciones y significaciones ciudadanas frente a las políticas aplicadas, abriendo un conjunto amplio de preguntas y reflexiones en torno al impacto en los proyectos de vida de las personas. La transformación de estos no es producto de sólo el evento natural mismo y de sus condiciones local residents. The paper "Emergent Subjects: Collective Acts of Resistance and Risk Confrontation in the Face of Disasters; the Case of Chaiten, Chile", co-authored by Ana Maria Ugarte and Marcela Salgado presents the conflictive relationship between the affected population and the public policies implemented to these days. Despite the long history of socio-natural disasters in Chile, the eruption of the Chaiten Volcano and the February 2010 earthquake and tsunami have finally triggered the systematization and the formulation of theories about public policies, risk and reconstruction processes. The contribution acts as a log of valuations and interpretations of citizens regarding implemented policies, thus opening a series of questions and reflections about the impact of these situations in the life projects of people. The transformation of these projects is not only the result of the natural event and previous social conditions, but is the alarming performance of the State in response to such a disaster.

Lastly, Teresinha Maria Gonçalves, in her contribution "Inhabiting. The House as a Contingency of Human Condition", finds inspiration in Heidegger and Bachelard to explore in the form of essay the identity appropriation processes of housing and habitat on the part of dwellers. This paper brings dwellers, an actor that has been constantly overlooked in his symbolic and sensitive dimension by politics, into the focus of the housing process; 
sociales anteriores, sino, y es aquí lo preocupante, de la errática acción del Estado como respuesta al desastre.

El artículo "Habitar. A casa como contingência da condição humana", de Teresinha Maria Gonçalves, se inspira en Heidegger y Bachelard para explorar en forma ensayística los procesos de apropiación identitaria de la vivienda y su hábitat por parte de sus moradores. De esta forma, el artículo trae al centro del proceso habitacional al habitante mismo, actor habitualmente ignorado en su dimensión simbólica y sensible por parte de la política, siendo este, paradójicamente, la principal fuente de su sentido.

En tiempos de transformaciones políticas se suele ver con mayor interés y atención la reflexión científica en torno a los hechos de realidad. Estamos seguros que este número de la Revista INVI es una fuente para pensar los cambios en un sentido similar al que la nueva presidenta chilena ha afirmado. paradoxically, it turns out that dwellers are the raison d'etrê of politics.

In these times of political transformations, scientific reflection on reality facts tends to be followed with more interest and attention. We are sure this issue of Revista INVI constitutes a source to reflect on changes in the same way as the new Chilean President has claimed. 